\title{
MODELING AND SIMULATION OF AN INDUSTRIAL INDIRECT SOLAR DRYER FOR IROKO WOOD (Chlorophora excelsa) IN A TROPICAL ENVIRONMENT
}

\author{
Merlin Simo-Tagne ${ }^{1, \star}$, André Zoulalian'2, Romain Remond ${ }^{3}$,Yann Rogaume ${ }^{3}$, \\ Beguidé Bonoma ${ }^{4}$
}

\begin{abstract}
This paper presents a modeling of an instrumental indirect solar wood dryer less expensive functioning in a Cameroonian climate applied to the climate of Yaoundé. The dryer is easy to build and electric energy is only used for the fan. Applications are done on Iroko wood (Chlorophora excelsa), a tropical wood $50 \mathrm{~mm}$ thick most utilized in Africa. A satisfactory agreement between experimental and numerical results was found. Influences of thickness, wood initial water content and airflow rate were studied.
\end{abstract}

Keywords: Drying curves, numerical simulation, solar greenhouse dryer, tropical climate, tropical woods.

\section{INTRODUCTION}

In Cameroon, forest exploitation gives provides considerable to the state. In addition, natural forests represent an important area. Iroko (Chlorophora excelsa) is prohibited exporting in the form of rough lumber. Then, it is very important to develop the first transformations in the country. For this reason, the reflections to optimize the drying are necessary in function of the local realities. Locally, after sawing, natural drying is used in the majority to dry wood. This method is known to have a lot of drying time and to destroy more boards than solar drying in an appropriate dryer. Solar drying is a method recommended where sustainable development is essential to reduce the environment impact of the industrial activities.

Cameroon has good solar potential with an average incident solar energy from $4,5 \mathrm{kWh} / \mathrm{m}^{2}$ in the south and $5,8 \mathrm{kWh} / \mathrm{m}^{2}$ daily in the great north (Ayangma et al. 2008). For example, the study of Ayangma et al. (2008) using 20 years data and applied in Garoua, a city of the great north region of

\footnotetext{
${ }^{1}$ LERMaB, Post-Doctoral position, 27 rue Philippe Séguin, P.O. Box 1041, F-88051 Epinal, France.

${ }^{2}$ University of Lorraine, LERMaB, Faculty of Sciences and Technologies, Aiguillettes Campus, P.O. Box 70239-54506 VIN, Nancy, France.

${ }^{3}$ University of Lorraine, LERMaB, ENSTIB, 27 rue Philippe Séguin, P.O. Box 1041, F-88051 Epinal, France.

${ }^{4}$ Higher Teacher's Training College, Applied Physic Laboratory, P.O.Box 47, Yaoundé, Cameroon.

•Corresponding author: simotagne2002@yahoo.fr

Received: 17.01.2016 Accepted: 20.11.2016
} 
Cameroon gives an estimation near $5,743 \mathrm{kWh} /\left(\mathrm{m}^{2}\right.$.day $)$. Another works in the literature such as Lealea and Tchinda (2013) and Njomo and Wald (2006) present some estimations of solar irradiation of many Cameroonian towns in general. Figure 1 presents the position of Cameroon's incident solar energy with some others developing countries.

In the literature, we have solar dryers with the wall in glass or with energy storage (Awadalla et al. 2004, Bauer 2003, Bekkioui 2009, Bekkioui et al. 2009, Bekkioui et al. 2011, Bentayeb et al. 2008a, Bentayeb et al. 2008b, Luna 2008, Luna et al. 2010). These dryers are very expensive for the level of development of many people coming in tropical region. Mathematical modeling is an essential tool that facilitates the understanding of the physical phenomena occurring in the product to dry during solar drying. It is possible to numerically model a dryer in order to give the characteristics to impose during the construction and to satisfy the needs of a population.

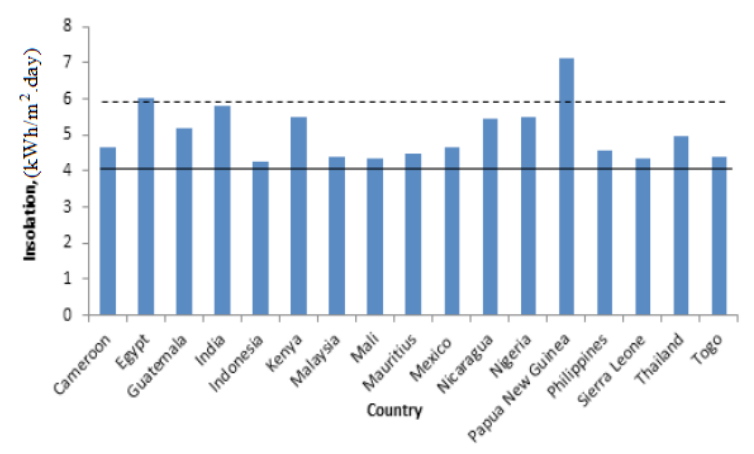

Figure 1. Global solar irradiation on a horizontal plane of some developing countries (Weiss and Buchinger 2003)

In this work, a modeling and a numerical simulation of the instrumental solar dryer of tropical woods coming from Cameroon are done. The price of construction of this simple dryer is low. The environment of the drying is the one of Yaoundé. Experiments are done from $22^{\text {th }}$ November to $12^{\text {th }}$ December 2004. Before, we present a model for the desorption isotherms based on experimental values presented in the literature.

\section{MATERIAL AND METHODS}

\section{Modeling of the desorption isotherms}

We have used experimental values (Jannot et al. 2006) to propose a relation for the isotherms of desorption. For the equilibrium moisture content $\left(\mathrm{X}_{\mathrm{eq}},{ }^{-}\right)$as a function of temperature $(\mathrm{T}, \mathrm{K})$ and fractional relative humidity (HR,-), we obtained:

$$
\begin{aligned}
& X_{e q}=\frac{b_{1} X_{m} H R}{\left(1-b_{2} H R\right)\left(1-b_{2} H R+b_{1} H R\right)} \\
& X_{m}=-7,33 \times 10^{-4} T+0,286 ; \quad R^{2}=0,994
\end{aligned}
$$




$$
\begin{array}{ll}
b_{2}=1,931 \exp \left(\frac{-2308,798}{R T}\right) ; & \mathrm{R}^{2}=0,919 \\
b_{1}=27,827 \exp \left(\frac{-2135,87}{R T}\right) ; & \mathrm{R}^{2}=0,324
\end{array}
$$

Figure 2a illustrates the equilibrium moisture content of the desorption summarized in Eq (1a).

The fractional moisture content at the fiber saturation point $\left(X_{P S F},-\right)$ is obtained using Eq (1a) with a value of 1 for relative humidity. This is presented in $\mathrm{Eq}(2)$ and plotted as a function of temperature in Figure $2 b$.

$$
X_{f s p}=\frac{b_{1} X_{m}}{\left(1-b_{2}\right)\left(1-b_{2}+b_{1}\right)}
$$

(a)

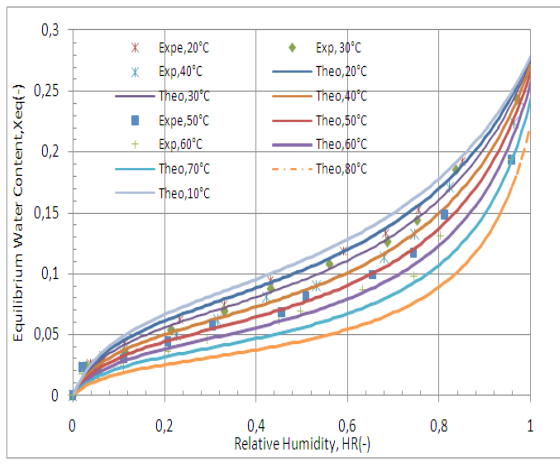

Figure 2. (a) Experimental and theoretical (Dent's model) isotherms of desorption of Iroko wood and (b) evolution of the fiber saturation point versus temperature.

\section{Solar data}

The drying was done in Yaoundé. After using the data given in Kemajou et al. (2012), we obtained Equations (3a) and (3b) of the correlations of experimental values of diffuse and global insulation on a horizontal plane in Yaoundé respectively. Geographical coordinates of Yaoundé are: Latitude: $3,87^{\circ} \mathrm{N}$; Longitude: $11,52^{\circ} \mathrm{E}$; Altitude: $720 \mathrm{~m}$ (Afungchui and Neba-Ngwa 2013).

$$
\begin{aligned}
& D=0,12152 t^{4}-5,44546 t^{3}+76,93216 t^{2}-349,09338 t+357,73432 ; R^{2}=0,99967 \\
& G_{t}=0,51681 t^{4}-24,19623 t^{3}+386,86802 t^{2}-2427,06266 t+5207,34134 \quad ; R^{2}=0,99882
\end{aligned}
$$

Using the relationships given in Appendix A, we have deduced the global irradiations on a slope plane at $10^{\circ}(3 \mathrm{c})$ and on the wall at $90^{\circ}(3 \mathrm{~d})$. 
$G_{t}^{*}\left(10^{\circ}\right)=-0,02411 t^{5}+1,86434 t^{4}-53,12658 t^{3}+685,0667 t^{2}-3906,6173 t+8037,91894 ; R^{2}=0,99$

$$
\mathrm{G}_{\mathrm{t}}^{*}(\text { Wall })=0,12073 \mathrm{t}^{4}-5,32896 \mathrm{t}^{3}+74,29878 \mathrm{t}^{2}-332,08327 \mathrm{t}+312,788 \quad ; \mathrm{R}^{2}=0,9913
$$

Where $t$ is the time of the day in hour. Between $6 \mathrm{am}$ and $6 \mathrm{pm}, \mathrm{Gt}^{*}$ is given by $(3 \mathrm{c})$ and $(3 \mathrm{~d})$ on the slope and the wall respectively. At night, $\mathrm{Gt}^{*}$ is equal to zero. Figure 3 presents the diffuse and global solar irradiation on horizontal plane experimentally obtained by Kemajou et al. (2012) and estimations of theses physical parameters on inclined plane with $10^{\circ}$ angle.

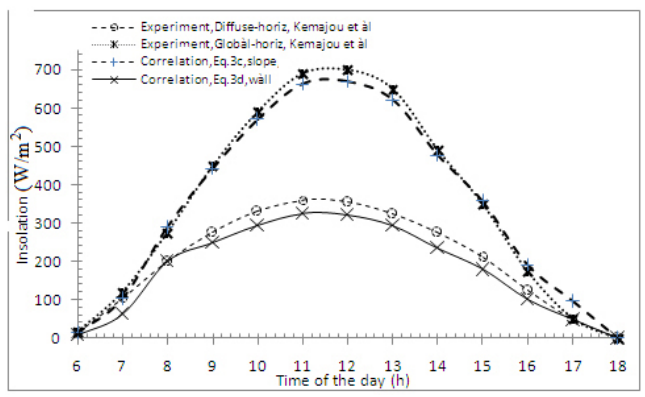

Figure 3. Global irradiations on a slope plane at $10^{\circ}$ angle and on the wall (Kemajou et al. 2012).

\section{Solar dryer design}

The fan is the type SK012/4EHBWC. The electrical characteristics are $0,37 \mathrm{~kW}$ power, $1350 \mathrm{tr} / \mathrm{min}$ rate of rotation, $3,6 \mathrm{~A}$ intensity, $240 \mathrm{~V}$ tension and $50 \mathrm{~Hz}$ frequency. The dryer dimensions are $3,10 \mathrm{~m}$ length $2,40 \mathrm{~m}$ width and $2,75 \mathrm{~m}$ west height. The roof at the slope of 10 degrees with horizontal. The floor is well insulated to reduce the heat losses. Black body situated at the top of the dryer is made in a steel sheet (aluminum) with an inclination 10 degrees with horizontal, smooth $5^{\mathrm{e}} / 10^{\mathrm{e}}$. Another physical parameters of the steel sheet are $0,5 \mathrm{~mm}$ thickness, $2 \mathrm{~m}$ length, $1 \mathrm{~m}$ width and $2,7 \mathrm{~kg}$ mass. The air volume in the dryer is equal to the dryer volume with the reduction of the volume of all other component located in the dryer. The obtained air volume is equal to $13 \mathrm{~m}^{3}$. Layout of the dryer is presented in Figure 4.

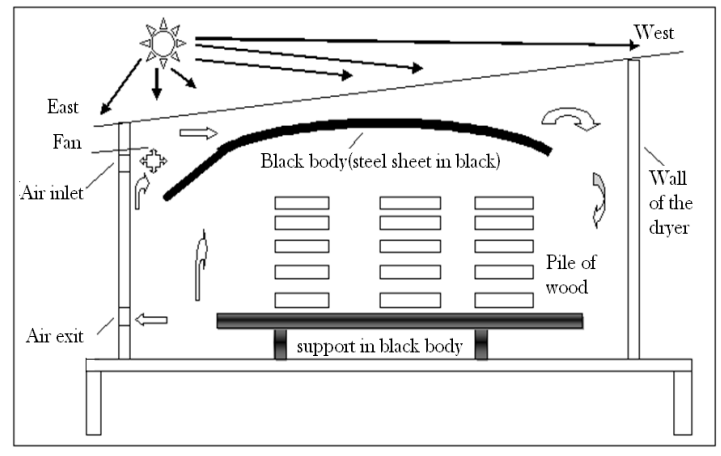

Figure 4. Schematic representation of the indirect solar dryer.

The wall and the slope are made in polyethylene. We have $3,7 \mathrm{~kg}$ and $5,28 \mathrm{~m}^{2}$ respectively the mass and surface of the east side wall. $4,623 \mathrm{~kg}$ and $6,6 \mathrm{~m}^{2}$ are respectively the mass and surface 
of the west side wall. The north and south sides have the mass and surface respectively equal to $5,374 \mathrm{~kg}$ and $7,673 \mathrm{~m}^{2}$. The mass and surface of the slope are $5,292 \mathrm{~kg}$ and $7,555 \mathrm{~m}^{2}$ respectively.

\section{Wood stack characteristics}

We have 14 layers with 4 boards by layer. Two consecutive layers are separated by the sticks and each stick dimensions are $220 \mathrm{~cm}$ length and $3,5 \mathrm{~cm}$ thickness. Each board in the wood stack has $5 \mathrm{~cm}$ thickness, $220 \mathrm{~cm}$ length and $38,5 \mathrm{~cm}$ width. Thus, the wood stack porosity is equal to 0,412 . The total board surface and the total wood stack volume are respectively equal to $97,16 \mathrm{~m}^{2}$ and $2,156 \mathrm{~m}^{3}$. Using the wood stack characteristics and the dryer dimensions, we obtained a fill factor (FF) equal to 0,195 .

\section{Modeling of the Dryer}

Hypotheses taken are:

*Each component inside the dryer is homogeneous;

*The thermophysical characteristics of the air are only influenced by the temperature. The thermophysical characteristics of the black body and the wall are constant;

*The entire wall has the same global solar radiation;

*We neglected the variation between the days of the global solar radiation;

*Natural convection is neglected;

*The floor of the dryer is supposed adiabatic;

*Transfers by conduction are neglected on all components of the dryer.

\section{Model equations}

Mass transfer on the wood stack:

We have used a purely diffusive mass transfer model such as Ananías et al. (2009, 2011), Bekkioui (2009), Bekkioui et al. (2009, 2011) and Bentayeb et al. (2008a, 2008b):

$$
-m_{0} \frac{d x}{d t}=K S_{b}\left(X-X_{e q}\right)
$$

With: $\quad m_{0}=\rho_{0}(1-\varepsilon) \mathrm{V}_{\mathrm{p}}=1108,26 \mathrm{Kg}$ and $S_{b}=2 L p N_{c}\left(l N_{p c}+e_{t}\right)=97,16 m^{2}$. We have used $\rho_{0}=514,1 \mathrm{Kg} / \mathrm{m}^{3} \quad$ (Gérard et al. 1998).

Applied on temperate and Chilean woods, the literature proposes the variation of the global mass transfer coefficient $\mathrm{K}$ in function of the air temperature, air velocity, air relative humidity, fiber saturation point and equilibrium water content given on Equation (5) (Alvear et al. 2003, Ananías et al. 2009, Ananías et al. 2011, Bekkioui 2009, Bekkioui et al. 2009, Bekkioui et al. 2011, Bentayeb et al. 2008a, Bentayeb et al. 2008b): 


$$
\frac{1}{K}=a_{0} \exp \left(\frac{C_{0}}{T_{a}}\right) e+b_{0} \exp \left(\frac{C_{0}}{T_{a}}\right) V_{\text {int }}^{-p} \exp \left(-\frac{1-H R}{X_{f s p}-X_{e q}}\right)
$$

$\mathrm{a}_{0}=0,2265 \mathrm{~ms} / \mathrm{kg} ; \mathrm{b}_{0}=268,9 \mathrm{~m}^{2} / \mathrm{kg} ; \mathrm{c}_{0}=2543,6 \mathrm{~K} ; \mathrm{p}=2,7158$

In this relation, e is used expressed in mm (Chrusciel et al. 1999). Simo-Tagne et al. (2016) show that it is possible to use the same influences of the global mass transfer coefficient in the case of tropical woods.

To estimate the external air temperature, we have used the relation (Benlahmidi 2013):

$$
T_{a e x t}=\frac{T_{a \min }+T_{a \max }}{2}+\frac{T_{a \max }-T_{a \min }}{2} \operatorname{Cos}\left(\pi \frac{t-12}{12}\right)
$$

We have $\mathrm{T}_{\text {amax }}=303,75 \mathrm{~K}$ and $\mathrm{T}_{\text {amin }}=292,95 \mathrm{~K}$. Initially, we have taken the temperature of all the component of the dryer equal to the value $\frac{T_{a \min }+T_{a \max }}{2}$.

\section{Mass transfer of air}

The global mass balance of water in the dryer is given by Eq(7) taken from Bekkioui (2009), Bekkioui et al. $(2009,2011)$ and Bentayeb et al. (2008a, 2008b).

$$
G\left(Y_{s}-Y_{E}\right)+m_{a} \frac{d Y_{s}}{d t}+\rho_{0}(1-\varepsilon) V_{p} \frac{d X}{d t}=0
$$

With

$$
m_{a}=\rho_{a}\left(V_{\text {dryer }}-(1-\varepsilon) V_{p}\right)
$$

$\mathrm{G}=0,05 \mathrm{~kg} / \mathrm{s}$.

Air relative humidity (HR,-) is given by:

$$
\begin{aligned}
& H R=\frac{P_{a t m}}{P_{v s a t}} \frac{Y_{s}}{0,622+Y_{s}} \\
& \mathrm{P}_{\text {atm }}=101325-12 \mathrm{z}+5,2 \times 10^{-4} \mathrm{z}^{2} \quad \text { (Galilée 2005) }
\end{aligned}
$$

with $z=720 \mathrm{~m}$ for Yaoundé (Afungchui and Neba-Ngwa 2013).

$$
P_{v s a t}=1,013125 \times 10^{5} \exp \left(13,7-\frac{5120}{T_{a}}\right),(\text { Nadeau and Puiggali 1995) }
$$

\section{Thermal transfer on the wood stack}

We haveneglected the exchange between the wood stack and the floor, also between the wood stack and thecover.Thustherateofaccumulationofthermalenergyintheproductisequaltothesumoftherateofthermal energy gain from the product due to sensible and latent heat, the rate of thermal energy received from air by the product due to convection and the rate of radiation between black body and wood stack. Thus we have: 


$$
m_{0} C_{p b} \frac{d T_{b}}{d t}=-K\left(L+E_{b}\right) S_{b}\left(X-X_{e q}\right)+h_{b} S_{b}\left(T_{a}-T_{b}\right)+\sigma S_{b b} F_{b b-b}\left(T_{t o}^{4}-T_{b}^{4}\right)
$$

\section{Thermal transfer of the air}

The rate of accumulation of thermal energy in the air inside the dryer is written as the sum of the rate of solar energy accumulated inside dryer from solar radiation through the roof and the wall respectively, the rate of thermal energy change in the air chamber due to inflow and outflow of the air in the chamber, the rate of thermal energy loss from air inside due to latent heat, the rates of thermal energy exchanged by convection between inside air and the roof, between inside air and the wall, between inside air and the black body and between inside air and wood stack respectively. Thus we have:

$$
\begin{aligned}
& m_{a} C_{p a} \frac{d T_{a}}{d t}=\left(1-\alpha_{p}\right) S_{p} G_{t} *\left(10^{\circ}\right)+\left(1-\alpha_{p 1}\right) S_{p 1} G_{t}^{*}(\mathrm{Wall})+\mathrm{GC}_{\mathrm{pa}}\left(T_{a e x t}-T_{a}\right)+G L\left(Y_{E}-Y_{S}\right)-h_{c i} S_{p}\left(T_{a}-T_{p}\right) \\
& -h_{c i l} S_{p l}\left(T_{a}-T_{p l}\right)-h_{c t o} S_{t o}\left(T_{a}-T_{t o}\right)-h_{c b} S_{b}\left(T_{a}-T_{b}\right)
\end{aligned}
$$

\section{Thermal transfer on the black body}

The rate of accumulation of thermal energy in the black body situated on the top of the drying chamber is equal to the sum of the rate of solar energy transferred by the roof and accumulated on the black body from solar radiation, the rate of thermal energy transfer by convection between the inside air and the black body, the rates of thermal energy exchanged by radiation between the roof and the black body, between the black body and the wall and between the black body and the wood stack respectively. Thus we have:

$$
\begin{aligned}
& m_{t o} C_{p t o} \frac{d T_{t o}}{d t}=\tau_{p} \alpha_{\mathrm{to}} S_{t o} G_{t} *\left(10^{\circ}\right)-h_{t o} S_{t o}\left(T_{t o}-T_{a}\right)-\sigma \mathrm{S}_{\mathrm{to}} F_{t o-p}\left(T_{t o}{ }^{4}-T_{p}^{4}\right)-\sigma \mathrm{S}_{p l} F_{p l-t o}\left(T_{t o}{ }^{4}-T_{p l}{ }^{4}\right) \\
& -\sigma \mathrm{S}_{t o} F_{t o-b}\left(T_{t o}{ }^{4}-T_{p}{ }^{4}\right)
\end{aligned}
$$

\section{Thermal transfer of the roof slope in polyethylene}

The rate of accumulation of thermal energy in the roof is equal to the sum of the rate of solar energy accumulated in the roof from solar radiation, the rate of thermal energy exchanged by radiation between the roof and the black body, and between the roof and the sky, the rate of thermal energy transferred by convection between the inside air and the roof, also between the outside air and the roof. Thus we have:

$$
\begin{aligned}
& m_{p} C_{p p} \frac{d T_{p}}{d t}=\alpha_{p} S_{p} G_{t} *\left(10^{\circ}\right)+\sigma S_{p} F_{p-t o}\left(T_{t o}{ }^{4}-T_{p}{ }^{4}\right)+\sigma \mathrm{S}_{\mathrm{p}} \mathrm{F}_{\mathrm{p}-\text { ciel }}\left(T_{\text {ciel }}{ }^{4}-T_{p}{ }^{4}\right)-\frac{1}{2} S_{p} h_{\text {vint }}\left(T_{p}-T_{a}\right) \\
& -\frac{1}{2} S_{p} h_{\text {vext }}\left(T_{p}-T_{\text {aext }}\right)
\end{aligned}
$$

\section{Thermal transfer on the wall of the dryer}

Therateofaccumulationofthermalenergyinthewall(polyethylenecover)isequal tothesumoftherate of solar energy accumulated in the wall from solar radiation, the rate of thermal energy transfer by convection between the inside air and the wall, also between the outside air and the wall, the rate of thermal energy exchanged by radiation between the wall and the blackbody, and between the wall and the sky. Thus wehave: 


$$
\begin{aligned}
& m_{p l} C_{p p l} \frac{d T_{p l}}{d t}=\alpha_{p l} S_{p l} G_{t} *(\text { Wall })-\frac{1}{2} S_{p l} h_{c i n t}\left(T_{p l}-T_{a}\right)-\frac{1}{2} S_{p l} h_{c e x t}\left(T_{p l}-T_{a e x t}\right)+\sigma \mathrm{S}_{\mathrm{pl}} \mathrm{F}_{\mathrm{pl}-\mathrm{to}}\left(T_{t o}{ }^{4}-T_{p l}{ }^{4}\right) \\
& +\sigma \mathrm{S}_{\mathrm{pl}} \mathrm{F}_{\mathrm{pl}-\text { ciel }}\left(T_{\text {ciel }}{ }^{4}-T_{p l}{ }^{4}\right)
\end{aligned}
$$

The relations below are used in the program. Form factors are obtained after calculations with the dimensions of the components of the dryer.

$$
\begin{gathered}
T_{\text {ciel }}=0,0552 T_{\text {aext }}^{1,5} \\
h_{\text {cext }}=5,67+3,86 V_{\text {ext }} \\
\mathrm{V}_{\text {ext }}=1,3 \mathrm{~m} / \mathrm{s} \quad(\text { meteorological data }), \quad \mathrm{V}_{\mathrm{int}}=1,5 \mathrm{~m} / \mathrm{s} ; \mathrm{h}_{\mathrm{ciL}}=7 \mathrm{w} /\left(\mathrm{m}^{2} \mathrm{~K}\right) ; \mathrm{h}_{\mathrm{ci}}=8 \mathrm{w} /\left(\mathrm{m}^{2} \mathrm{~K}\right) ; \quad \mathrm{h}_{\mathrm{cto}}=8 \mathrm{w} /\left(\mathrm{m}^{2} \mathrm{~K}\right) ; \\
h_{b}=\frac{N_{u} \lambda_{\text {air }}}{D_{h}} ; N_{u}=0,023 R_{e}^{0,8} P_{r}^{0,33} ; R_{e}=\frac{V_{\text {int }} D_{h}}{u_{\text {air }}} ; D_{h}=2 e_{t}
\end{gathered}
$$

We have $\mathrm{Re}=5687,36 ; \mathrm{D}_{\mathrm{h}}=0,07 \mathrm{~m} ; \operatorname{Pr}=0,708 ; \lambda_{\text {air }}=0,026248 \mathrm{w} /(m K) ; \mathrm{h}_{\mathrm{cb}}=8 \mathrm{w} /\left(\mathrm{m}^{2} \mathrm{~K}\right)$. Thus we have $h_{b}=7,77 \mathrm{w} /\left(\mathrm{m}^{2} \mathrm{~K}\right)$.

The thermophysical correlations on the wood and on the component of the dryer are taken in the literature Simo-Tagne (2014) and Simpson and TenWolde (1999). Those of air, black body (in aluminum) and wall (in polyethylene) are taken in the literature (Jannot 2011, Lienhard IV and Lienhard V 2011, Nadeau and Puiggali 1995). We have:

$$
\begin{gathered}
\mathrm{C}_{\mathrm{pto}}=900 \mathrm{~J} /(\mathrm{kg} \cdot \mathrm{K}) ; \mathrm{C}_{\mathrm{pp}}=\mathrm{C}_{\mathrm{ppL}}=2300 \mathrm{~J} /(\mathrm{kg} \cdot \mathrm{K}) ; \alpha_{p}=\alpha_{p L}=0,05 ; \alpha_{t o}=0,91 ; \tau_{p}=0,95 ; \\
C_{p a}=1835-0,734\left(T_{a}-273,15\right) \\
L=1000\left(3335-2,91 T_{a}\right) \\
E_{b}=1170,4 \times 10^{3} \exp (-14 X) \\
C_{p b}=\frac{C_{p o}+X C_{p w}}{1+X}+X\left(-6,191 \times 10^{-4}+2,36 \times 10^{-6} T_{b}-1,33 \times 10^{-8} X\right) \\
C_{p o}=0,1031+3,867 x 10^{-3} T_{b} ; C_{p w}=4190 \mathrm{~J} /(\mathrm{Kg} \cdot \mathrm{K})
\end{gathered}
$$

Second term of second member of (17e) is equal to zero in a non-hygroscopic domain, domain that is limited by the water content at the fiber saturation points. The geometric factor is obtained using the method developed in Clark and Korybalsky (1974). This method is also used by Bekkioui (2009), Bekkioui et al. $(2009,2011)$ and Bentayeb et al. (2008). We have obtained: 
$\mathrm{F}_{\text {top }}=0,537 ; \mathrm{F}_{\text {pciel }}=0,8 ; \mathrm{F}_{\mathrm{pto}}=0,81 ; \mathrm{F}_{\mathrm{pLto}}=0,75 ; \mathrm{F}_{\text {tob }}=0,3 ; \mathrm{F}_{\mathrm{bbb}}=0,323$ error:

The parameter used to compare experimental and numerical results is given by the average relative

$$
E_{r}(\%)=\frac{100}{N} \sum_{i=1}^{N} \frac{\left|X_{t h_{i}}-X_{\exp _{i}}\right|}{\frac{X_{t h_{i}}+X_{\exp _{i}}}{2}}
$$

\section{Method of Resolution and Experimental Drying Process}

\section{Method of resolution}

Finite difference method (Gonçalves 2005) is used to resolve equation relative to the mass transfer on the air (Eq. 7). We obtained:

$$
Y_{s, t 1}=\frac{Y_{s, t o} m_{a}+m_{o}\left(X_{t o}-X_{t 1}\right)+G Y_{E, t 1} \Delta t}{m_{a}+G \Delta t}
$$

Known air humidity of the air at the time $\mathrm{t}_{0},\left(Y_{s, t o}\right)$ we deducted the air humidity at the time

$t_{1}=t_{0}+\Delta t\left(Y_{s, t 1}\right)$. For all the others relations, we have used Runge Kutta method in the order 4 (Gonçalves 2005). For example, Eq.10 is treated such as the following:

$$
\begin{gathered}
A\left(t_{n}, T_{b n}\right)=-K\left(L+E_{b}\right) S_{b}\left(X-X_{e q}\right)+\mathrm{h}_{\mathrm{b}} \mathrm{S}_{\mathrm{b}}\left(\mathrm{T}_{\mathrm{a}}-\mathrm{T}_{\mathrm{b}}\right)+\sigma \mathrm{S}_{\mathrm{bb}} \mathrm{F}_{\mathrm{bb}-\mathrm{b}}\left(T_{t o}^{4}-T_{b}^{4}\right) \\
f\left(t_{n}, T_{b n}\right)=\frac{A\left(t_{n}, T_{b n}\right)}{m_{o} C_{p b}}
\end{gathered}
$$

Given $T_{b o}$ we have:

$$
k_{1}=\Delta t f\left(\mathrm{t}_{\mathrm{n}}, \mathrm{T}_{\mathrm{bn}}\right)
$$

$k_{2}=\Delta t f\left(\mathrm{t}_{\mathrm{n}}+\frac{\Delta t}{2}, \mathrm{~T}_{\mathrm{bn}}+\frac{k_{1}}{2}\right)$

$k_{3}=\Delta t f\left(\mathrm{t}_{\mathrm{n}}+\frac{\Delta t}{2}, \mathrm{~T}_{\mathrm{bn}}+\frac{k_{2}}{2}\right)$

$k_{4}=\Delta t f\left(\mathrm{t}_{\mathrm{n}}+\Delta t, \mathrm{~T}_{\mathrm{bn}}+k_{3}\right)$

$T_{b_{n+1}}=T_{b_{n}}+\frac{1}{6}\left(\mathrm{k}_{1}+2 k_{2}+2 k_{3}+k_{4}\right)$ 
Fortran language in the version 77 was used to generate our results and the step time used was $15 \mathrm{~s}$. We recorded our results each $1 \mathrm{hr}$ drying time.

\section{Experimental drying process}

The mission of promoting local materials of Cameroon (MIPROMALO) had built and experienced the solar dryer studied in this paper. After having positioned the wood stack, the fan is commanded ON. The air relative humidity inside is controlled after each two hours during the day. If the air relative humidity is more greater than 0,7 (near 0,9 ), the air inside is replaced by fresh outside air. When the air relative humidity inside is lower than 0,7 (near 0,3), the fresh air replaces the air inside the dryer. At night, inside air is exchanged each $1 \mathrm{hr}$ in order to avoid atmospheric saturation.

\section{RESULTS AND DISCUSSION}

Known that initial drying time 0 corresponds to $00 \mathrm{pm}$ (local time in Yaoundé). Figure 5 shows a satisfactory agreement between theoretical and experimental measurements. We have a average relative error $\mathrm{E}_{\mathrm{r}}$ equal to $4,49 \%$. From initial water content equal to $0,4 \mathrm{~kg} / \mathrm{kg}$ with the thickness equal to $50 \mathrm{~mm}$, 20 days are necessary to dry iroko wood to $0,15 \mathrm{~kg} / \mathrm{kg}$, Figure 5 .

Figure 6 shows the influence of the environment on the water content of our wood. During the night, equilibrium water content is great and it is weak at 12 o'clock. Then, the drying of wood stack is weak during the night. It is clear that in this condition, the wood stack dried until the equilibrium value of $0,11 \mathrm{~kg} / \mathrm{kg}$ after $768 \mathrm{~h}$ drying time, Figure 6 .

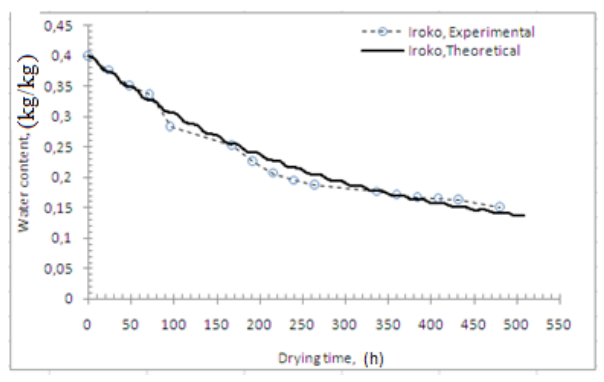

Figure 5. Experimental and theoretical water content evolution versus drying time, $50 \mathrm{~mm}$.

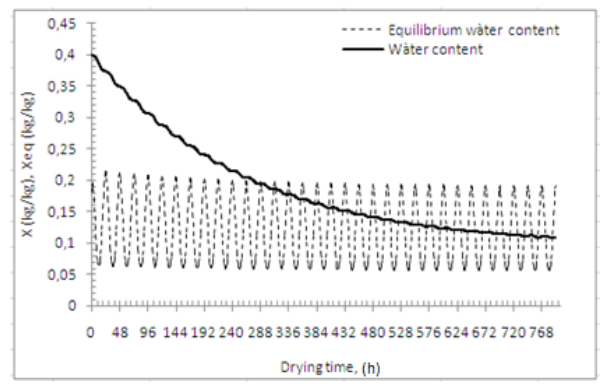

Figure 6. Theoretical water content and equilibrium water content evolutions versus drying time, 
$50 \mathrm{~mm}$.

If we want to use this solar dryer to dry our wood in order to use in a house in Yaoundé, knowing that the means values in the Yaoundé house are $\mathrm{HR}=0,727$ and $\mathrm{T}=24,8^{\circ} \mathrm{C}$ (Kameni et al. 2014), relation (1a) gives equilibrium water content equal to $0,144 \mathrm{~kg} / \mathrm{kg}$ for our wood. In the same experimental process and climatic conditions, our indirect solar dryer gives these equilibrium values after 18 days. Figure 7 shows the time variations of temperatures relative to the wood stack (red), to the interior air (blue) and to the black body (green) during 528hrs drying time. Curves are presented 528hrs of the drying process. We notice that the curves are similar evolutions than the temperature of the air outside the dryer. Black body absorbs most energy necessary to facilitate drying process during the night. Figure 8 shows that air relative humidity vary with the time. When air temperature increases, air relative humidity decreases. Also, air temperature inside the dryer is greater than air exterior with a difference equal to $10^{\circ} \mathrm{C}$.

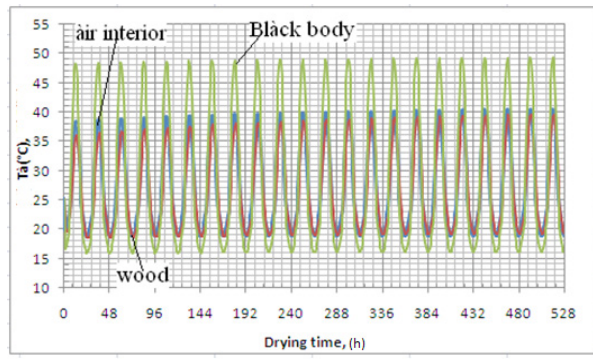

Figure 7. Predicted temperatures of wood stack, black body and air interior during the process, $50 \mathrm{~mm}$.

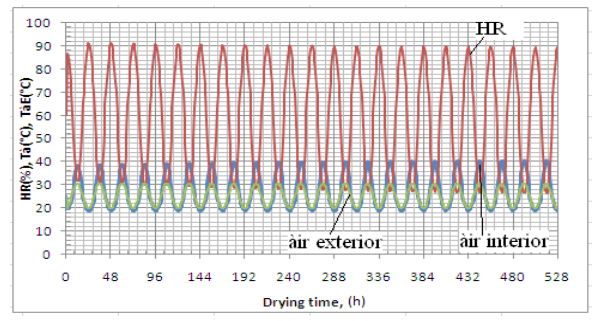

Figure 8. Theoretical relative humidity, outside air temperature and inside air temperature, $50 \mathrm{~mm}$.

Figure 9 presents the variation of average water content of wood stack with the drying time in function to the wood thickness numerically obtained. When wood thickness decreases, drying process is rapid. When the thickness changes, final water content is near than equilibrium water content.

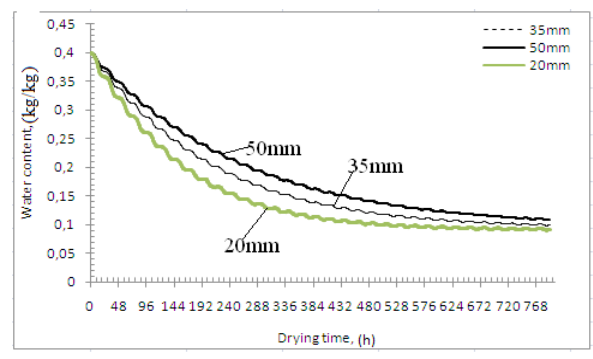

Figure 9. Predicted water content versus drying time and board thickness, $50 \mathrm{~mm}$. 
Figure 10a shows that the drying kinetic is fast when initial water content is important because it is easy to dry free water. Also, final water content of all curves at different initial water content is near to equilibrium water content. It is clear that, if initial water content or thicknesses of wood are different, final water content of each plank is different. Thus, it is important to do a pretreatment to the wood stack in order to homogenize initial water content of the stack. Also, it is possible to do this homogenization at the end of the drying process with an increase of interior air relative humidity. Figure 10b shows that when air flow rate increases, drying kinetic decreases. Increase of air flow rate helps to decrease the value of air temperature because communication between air drying and the components of the dryer is reduced. Figure 11 presents the consequence of two types of ventilation of the dryer. Open night conduct (in the night, we remove moist air in the dryer) helps to increase drying kinetic, compared to the case where in the night fan is stopped. When moist air is not remove in the night, it is possible that interior air humidity becomes more than the board humidity at the surface. Thus, the drying kinetic becomes very lowest comparing by the case where ventilation is not stopped. It is clear that the drying duration is great in the case where ventilation is stopped during the night.

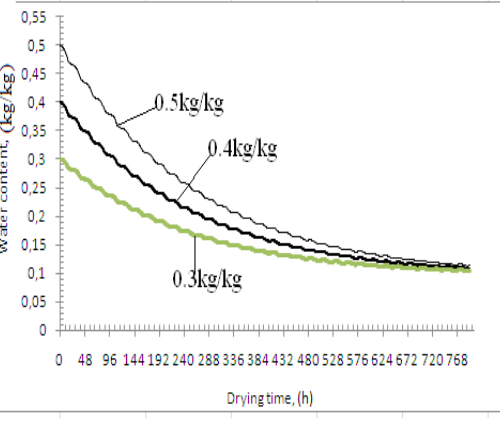

(a)

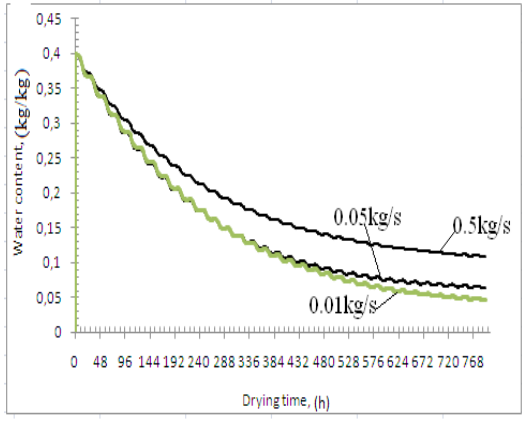

(b)

Figure 10. Predicted water content versus drying time with $50 \mathrm{~mm}$ of thickness. (a) Influence of initial water content, (b) influence of air flow rate.

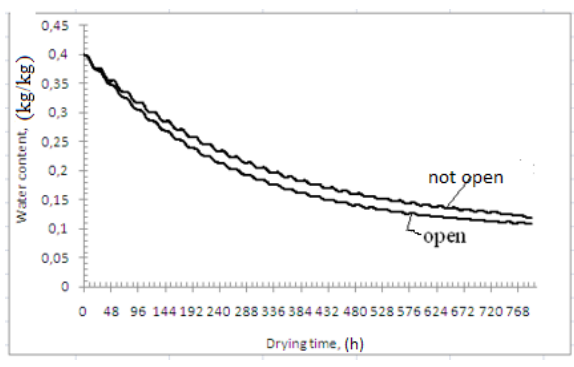

Figure 11. Predicted water content in function of the ventilation, $50 \mathrm{~mm}$. 


\section{CONCLUSIONS}

The model developed gives a satisfactory agreement in comparison with experimental results. The influences of initial wood water content, airflow velocity and board thickness on the drying process are conformed. Mathematical model proposed can be used to design the performing dryer in order to build in tropical region many indirect solar dryers less expensive. During drying process, it is important to homogenize initial water content and the board thickness in order to obtain a same drying kinetic of each board. At night, it is economically important to stop the fan and open the drying chamber when inside air is near saturation. In the future, it will interesting to discuss which terms are important to carefully characterize in this model.

\section{ACKNOWLEDGEMENTS}

The principal author acknowledges the International Tropical Timber Organization (ITTO) for financially supporting a part of this work (ITTO Ref. Number: 012/15A). The authors are grateful to the administration and all staff of the mission of promoting local materials of Cameroon (MIPROMALO) for the experimental data given and all explanations obtained in order to put it in our program. We acknowledge the two anonymous reviewers for all suggestions given to ameliorate the presentation of this paper.

\section{REFERENCES}

Afungchui, D.; Neba-Ngwa, R. 2013. Global solar radiation of some regions of Cameroon using the linear Angstrom and non-linear polynomial relations (part I) model development. International Journal of Renewable Energy Research 3(4):984-992.

Alvear, M.; Broche, W.; Salinas, C.; Ananias, R.A. 2003. Drying kinetic of Chilean coigüe: Study of the global drying coefficient. $8^{\text {th }}$ International IUFRO Wood Drying Conference: 383-387.

Ananías, R.A.; Chrusciel, L.; Zoulalian, A.; Salinas-Lira, C.; Mougel, E. 2011. Overall mass transfer coefficient for wood drying curves predictions. Mass Transfer in Multiphase Systems and its Applications. [on line] Prof. Mohamed El-Amin (Ed.), ISBN: 978-953-307-215-9, InTech. Available from: <http://www.intechopen.com/books/mass-transfer-in-multiphase-systems-and-its-applications/ overall-masstransfer-coefficient-for-wood-drying-curves-predictions $>$

Ananías, R.A.; Mougel, E.; Zoulalian, A. 2009. Introducing an overall mass-transfer coefficient for prediction of drying curves at low temperature drying rates. Wood Science and Technology 43(1):4356.

Awadalla, H.S.F.; El-Dib, A.F.; Mohamad, M.A.; Reuss, M.; Hussein, H.M.S. 2004. Mathematical modelling and experimental verification of wood drying process. Energy Conversion and Management (45):197-207.

Ayangma, F.; Nkeng, G.E. ; Bonoma, D.B.; Nganhou, J. 2008. Evaluation du potentiel en énergie solaire au Cameroun : Cas du Nord Cameroun. African Journal of Science and Technology, Science and Engineering series 9(2):32-40.

Bauer, K. 2003. Development and optimization of a low temperature drying schedule for Eucalyptus grandis (Hill) ex maiden in a solar assisted timber dryer. Ph.D. Thesis, Institut für Agrartechnik in den Tropen und Subtropen, Universität Hohenheim, Germany. 
Bekkioui, N. 2009. Séchage solaire du bois: modélisation simplifiée du séchage solaire d'une pile de bois dans un séchoir solaire à parois vitrées. Ph.D.Thesis, University of Mohammed V-AGDAL, Morocco.

Bekkioui, N.; Hakam, A.; Zoulalian, A.; Sesbou, A.; Kortbi, M.E. 2011. Solar drying of pin lumber: Verification of a mathematical model. Maderas. Ciencia y Tecnologia 13(1):29-40.

Bekkioui, N.; Zoulalian, A.; Hakam, A.; Bentayeb, F.; Sesbou, F. 2009. Modelling of a solar wood dryer with glazed walls. Maderas. Ciencia y Tecnologia 11(3): 191-205.

Benlahmidi, S. 2013. Etude du séchage convectif par l'énergie solaire des produits rouges. Ph.D.Thesis. University of Mohamed Khider-Biskra. Algeria.

Bentayeb, F.; Bekkioui, N.; Camacho, E. F. 2008b. Simulation of a solar dryer functioning in a Moroccan climate. VI Minsk International Seminar. Heat Pipes, Heat Pumps, Refrigerators : 214-219.

Bentayeb, F.; Bekkioui, N.; Zeghmati, B. 2008a. Modelling and simulation of a wood solar dryer in a Moroccan climate. Renewable Energy (33):501-506.

Chrusciel, L.; Mougel, E.; Zoulalian, A.; Meunier, T. 1999. Characterisation of water transfer in a low temperature convective wood drier: influence of the operating parameters on the mass transfer coefficient. Holz Roh Werkstoff (57):439-445.

Clark, J.A.; Korybalski, M.E. 1974. Algebraic methods for the calculation of radiation exchange in an enclosure. Warme-und Stoffubertragung 7:31-44.

Galilée, L.P. 2005. L'air humide Cours de climatisation, (Chapter 1). BTS Cours FEE $1{ }^{\text {ère }}$ Année.

Gérard, J.; Kouassi, A.E.; Daigremont, C.; Détienne, P.; Fouquet, D.; Vernay, M. 1998. Synthèse sur les caractéristiques technologiques de référence des principaux bois commerciaux africains. Série FORAFRI, Document 11, CF, CIRAD, CIFOR.

Gonçalves, E. 2005. Résolution numérique, discrétisation des EDP et EDO. Institut National Polytechnique de Grenoble.

Jannot, Y. 2011. Thermique solaire. Cours de transfert thermique.

Jannot, Y.; Kanmogne, A.; Talla, A.; Monkam, L. 2006. Experimental determination and modelling of water desorption isotherms of tropical woods: afzelia, ebony, iroko, moabi and obeche. Holz als Roh-und Werkstoff (64):121-124.

Kameni, N.M.; Tchinda, R.; Orosa, J.A.; Roshan, G. 2014. Study of dioxide carbon concentration and indoor àir quality in some buildings in the equatorial region of Cameroon (Yaoundé). Iranian Journal of Health Sciences 2(2):1-15.

Kemajou, A.; Mba, L.; Pako-Mbou, G. 2012. Energy efficiency in air-conditioned buildings of the tropical humid climate. IJRRAS 11(2):235-240.

Lealea, T.; Tchinda, R. 2013. Estimation of diffuse solar radiation in the South of Cameroon. Journal of Energy Technologies and Policy 3(6):32-42.

Lienhard IV, J.H.; Lienhard V, J.H. 2011. A heat transfer textbook. Fourth edition, Cambridge Massachusetts.

Luna, D.L. 2008. Modélisation et conception préliminaire d'un séchoir solaire pour bois de pin avec stockage d'énergie. Ph.D. Thesis, ENSAM, France.

Luna, D.L.; Nadeau, J.P.; Jannot, Y. 2010. Model and simulation of a solar kiln with energy storage. Renewable Energy 36(11):2533-2542. 
Nadeau, J.P.; Puiggali, J.R. 1995. Séchage, des processus physiques aux procédés industriels. Paris, New York, Londres, Tec and Doc.

Njomo, D.; Wald, L. 2006. Solar irradiation retrieval in Cameroon from meteosat satellite imagery using Helio_2 method. ISESCO Science and Technology Vision 2(1):19-24.

Simo-Tagne, M. 2014. Numerical study of heat and mass transfer during the thermal drying of tropical woods. International Journal of Thermal and Environment Engineering 8(2):9-15.

Simo-Tagne, M.; Monkam, L.; Rémond, R.; Zoulalian, A.; Rogaume, Y.; Beguide-Bonoma. 2016. Experimental determination of the global mass transfer coefficient of the tropical woods in order to deduce the drying curves at the lower temperature. International Journal of Thermal and Environment Engineering 12(1):9-14.

Simpson, W.T.; TenWolde, A. 1999. Physical properties and Moisture Relations of Wood. Chapter 3 from Forest Products Laboratory. Wood handbook.

Weiss, W.; Buchinger, J. 2003. Solar drying. AEEE INTEC.

\section{Appendix A}

(Jannot 2011)

$\mathrm{S}_{\mathrm{t}}=\mathrm{G}_{\mathrm{t}}-\mathrm{D} ; \mathrm{G}_{\mathrm{t}}, \mathrm{S}_{\mathrm{t}}$ and $\mathrm{D}$ are global, direct and diffuse insolation on horizontal plane.

For inclined plane i, we have:

$G^{*}(i, \gamma)=S^{*}(i, \gamma)+D^{*}(i, \gamma)+R^{*}(i, \gamma)$

$$
\begin{aligned}
& S^{*}(i, \gamma)=\frac{S}{\sin (h)}[\cos (h) \sin (i) \cos (a-\gamma)+\sin (h) \cos (i)] \\
& D^{*}(i, \gamma)=\frac{D}{2}[1+\cos (i)] \\
& R^{*}(i, \gamma)=\frac{G}{2} \rho[1-\cos (i)]
\end{aligned}
$$

$\rho$ is the albedo

$\mathrm{h}$ is height of the sun:

$$
\sin (\mathrm{h})=\sin (\text { Lat }) \sin (\delta)+\cos (\text { Lat }) \cos (\delta) \cos (\mathrm{w})
$$


$\sin (a)=\frac{\cos (\delta) \sin (w)}{\cos (h)}$

$a$ is azimuth; Lat is latitude; $\mathrm{i}$ is inclination angle; $\delta$ is declination; $\mathrm{w}$ is horar angle giving by

$\mathrm{w}=15^{\circ}(\mathrm{TS}-12)$

TS is Solar time expressed in $\mathrm{h}$.

$\delta=23,45^{\circ} \sin \left[0,98^{\circ}(j+284]\right.$

$\mathrm{j}$ day number in the year ;

$T S=T L-C+E T+\frac{l_{r e f}-\text { long }}{15}$

TL is the legal time (h), ET is Equation of the time (h) $l_{\text {ref }}$ and long are reference of longitude and longitude of the site $\left(^{\circ}\right)$ respectively. We have used $\mathrm{C}=1 \mathrm{~h}$ and $1_{\mathrm{ref}}=0^{\circ}$ for Yaoundé.

\section{Nomenclature}

$\mathrm{C}_{\mathrm{pa}} \quad: \quad$ mass heat of the air $(\mathrm{J} /(\mathrm{kg} \cdot \mathrm{K}))$;

$\mathrm{C}_{\mathrm{pto}} \quad: \quad$ mass heat of the black body $(\mathrm{J} /(\mathrm{kg} . \mathrm{K}))$;

$\mathrm{C}_{\mathrm{pb}} \quad: \quad$ mass heat of the wood (J/(kg.K));

$\mathrm{C}_{\mathrm{pp}} \quad: \quad$ mass heat of the roof slope (polyethylene) $(\mathrm{J} /(\mathrm{kg} \cdot \mathrm{K}))$;

$\mathrm{C}_{\mathrm{ppl}} \quad: \quad$ mass heat of the wall (polyethylene) $(\mathrm{J} /(\mathrm{kg} \cdot \mathrm{K}))$;

D : diffuse solar irradiation on a horizontal plane $\left(\mathrm{w} / \mathrm{m}^{2}\right)$;

$\frac{d}{d t} \quad: \quad$ derivative with respect of the drying time $\left(\mathrm{s}^{-1}\right)$;

e : thickness of the plank $(\mathrm{mm})$;

$\mathrm{E}_{\mathrm{b}} \quad: \quad$ desorption heat $(\mathrm{J} / \mathrm{kg})$;

$\mathrm{E}_{\mathrm{r}} \quad: \quad$ average relative error (\%);

$\mathrm{e}_{\mathrm{t}} \quad: \quad$ stick thickness (m);

$\mathrm{F}_{\mathrm{bb}-\mathrm{b}} \quad: \quad$ geometric factor black body-wood(-);

FF : volume of the wood stack divided by the volume of the dryer chamber (-); 


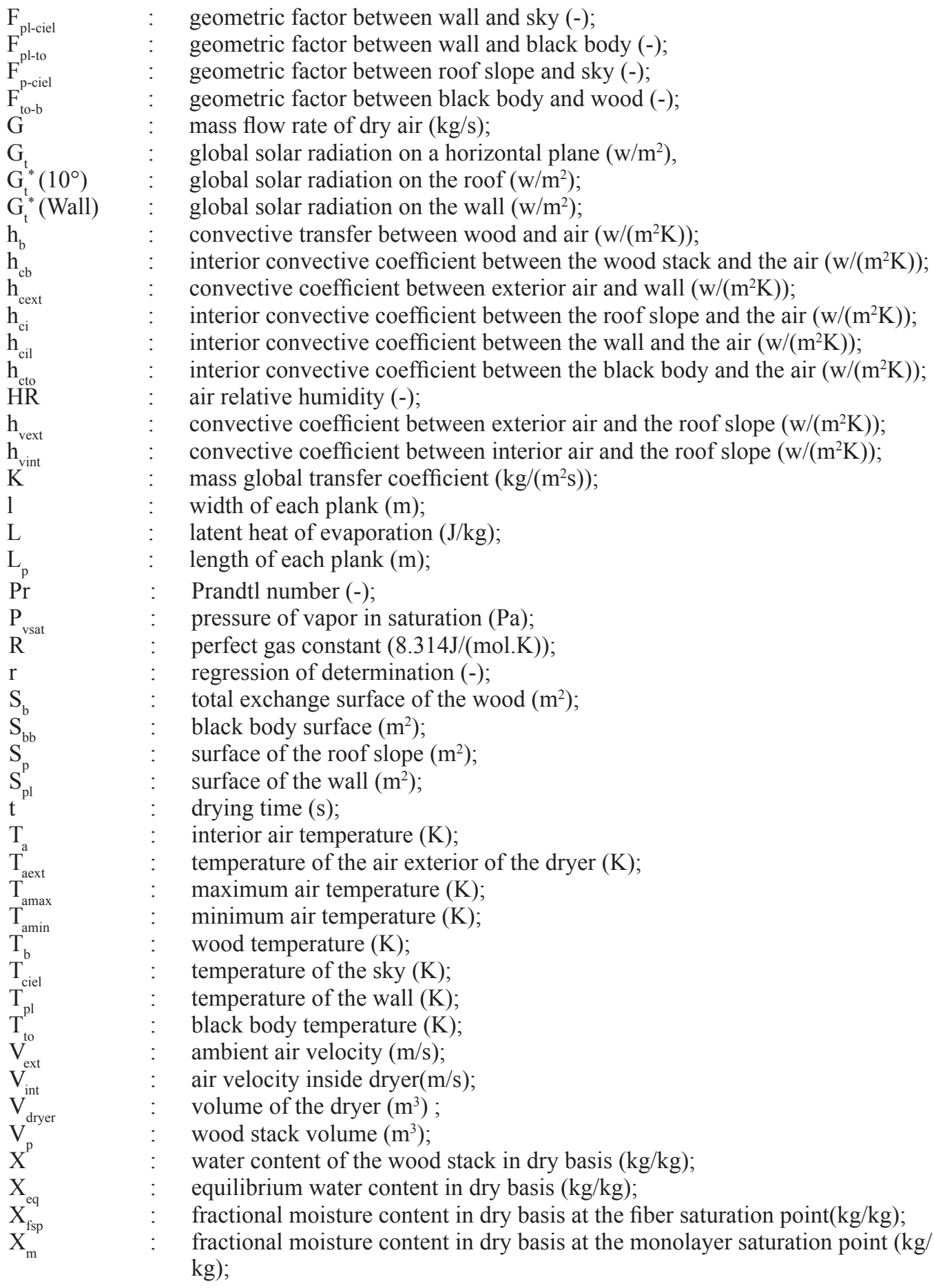


$X_{\exp _{\mathrm{i}}} \quad: \quad$ experimental water content of the wood stack in dry basic number i $(\mathrm{kg} / \mathrm{kg})$;

$X_{t h_{\mathrm{i}}} \quad: \quad$ theoretical water content of the wood stack in dry basic number $\mathrm{i}(\mathrm{kg} / \mathrm{kg})$;

$\mathrm{Y}_{\mathrm{E}} \quad$ : inlet air humidity of the dryer $(\mathrm{kg} / \mathrm{kg})$;

$\mathrm{Y}_{\mathrm{S}} \quad$ : inside air humidity of the dryer $(\mathrm{kg} / \mathrm{kg})$;

$\mathrm{z} \quad$ : altitude of the dryer (the one of the town)(m);

$\alpha_{\mathrm{p}} \quad: \quad$ absorptivity of the roof (-);

$\alpha_{\mathrm{pL}} \quad: \quad$ absorptivity of the wall (-);

$\alpha_{\text {to }} \quad: \quad$ absorptivity of the black body (-);

$\tau_{\mathrm{p}} \quad: \quad$ transmittivity of the roof and wall $(-)$;

$\lambda_{\text {air }}^{\mathrm{p}} \quad: \quad$ thermal conductivity of the $\operatorname{air}(\mathrm{W} /(\mathrm{m} . \mathrm{K}))$;

$\mu_{\text {air }} \quad: \quad$ dynamical viscosity of the air(Pa.s);

$\varepsilon \quad$ : wood stack porosity (-);

$\rho_{\mathrm{a}} \quad: \quad$ air density $\left(\mathrm{kg} / \mathrm{m}^{3}\right)$;

$\rho_{\mathrm{o}} \quad: \quad$ wood dry density $\left(\mathrm{kg} / \mathrm{m}^{3}\right)$;

$\sigma \quad$ : Stefan-Boltzmann constant value $\left(5,67 \times 10^{-8} \mathrm{~W} /\left(\mathrm{m}^{2} \mathrm{~K}^{4}\right)\right.$;

$\Delta \mathrm{t} \quad$ : time step (s);

|| : symbol of the absolute value. 